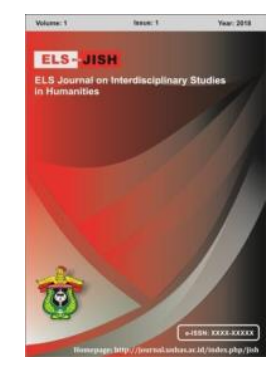

ELS-JISH

ELS Journal on Interdisciplinary Studies on Humanities

Volume 3 Issue 4, 2020

ISSN (print) : 2621-0843

ISSN (online) : 2621-0835

Homepage : http://journal.unhas.ac.id/index.php/jish

\title{
Strengths and Weaknesses of Self-Regulated Learning through YouTube: Indonesian EFL Students' Perceptions
}

\author{
Hj. Fadhilah Harahab Putri ${ }^{1}$, Agus Wijayanto ${ }^{2}$, Slamet Supriyadi ${ }^{3}$ \\ 1adhilah.harahab@gmail.com
}

\begin{abstract}
The recent advancements in technology are growing rapidly, because of that the demands of Internet are increasing rapidly. Include the use of website and application. Technology has brought various potentials for language learning. Therefore, in this research the aims are to determine the perceptions of EFL students and the strengths and weaknesses of self-regulated learning using YouTube. To achieve the objective of the research, the method used in this research is a case study. The data in this research were collected through in-depth interviews. The subjects in this research were four undergraduate students who are majoring in English education from university in Indonesia and they were purposively selected, so that they can provide sufficient information. The results in this research showed the positive perceptions of students towards EFL students self-regulated learning using YouTube. They declared that the use of YouTube could facilitate them in regulating their learning English, brings joy, pleasure and excitement during the learning process. In addition, in this research found out that the strengths of self-regulated learning using YouTube; YouTube provides a lot of learning materials, the ease to use YouTube, flexibility of time and place when using YouTube in regulating their learning. Meanwhile the weaknesses are financial constraints and problem of Internet connectivity.
\end{abstract}

Keywords: EFL Students' Perception, Strengths, Weaknesses, Self-regulated Learning, YouTube, Learning English

How to cite: Putri, H. F. H., Wijayanto, A. \& Supriyadi, S. (2020). Strengths and Weaknesses of Self-Regulated Learning through YouTube: Indonesian EFL Students' Perceptions. ELS Journal on Interdisciplinary Studies in Humanities, 3(4), 531-542. DOI: https://doi.org/10.34050/elsiish.v3i4.11749

\section{Introduction}

The recent advancements in technology are growing rapidly, because of that the demands of Internet are increasing rapidly. Include the use of websites and applications. Technology has brought various potentials for language learning such as: easily accessible to large amount of authentic language learning materials collections and learning supports, and exposures to engaging student learning experiences and environments, easily accessible to native speakers and language learners around the world (Thorne et al., 2009; Zhao, 2005). In addition of that learning process are no longer bound in classrooms.

\footnotetext{
${ }^{1,3}$ Sebelas Maret University, Indonesia

${ }^{2}$ Muhammadiyah University of Surakarta, Indonesia
} 
The advantages of technology in language learning may best be realized and maximized outside the classroom, because students' acceptance of the value of technology and the effective use of technology that is very important. Technology provides a place and makes it easier for students in regulating their language learning (McLoughlin \& Lee, 2010).

There are so many different resources that try to win students' attention when they are online. The norms in digital era are being multitasking and the spans students' short attention (Mokhtari et al., 2015), describing students' language learning outside the classroom in this virtual space continues to be an interesting research topic (Merchant, 2009). Furthermore in learning English is not adequate only from the books or teachers; it is needed to look for the other sources (Rahman and Amir, 2019). Due to the rapid development of technology especially in the world of education, videos on YouTube can be used as the learning sources. When students use video in their learning process, they find it very interesting, they are more motivated to learn, develop creativity, gain new experiences, gain understanding of different cultures (Hadijah, 2016). There are so many video platforms that can be used for student in their learning process such as Vimeo, iTunes, Google video, but of the many platforms, the most widely used today by people is YouTube ((Muhammad et al., 2014). YouTube was launched in 2005. Since then YouTube has continued to grow and has become a very popular video platform where people can enjoy various types of videos, can download them for free, and even share with friends (Chau, 2010). On the YouTube platform, there are various types of video content that can be watched, for example about music, entertainment, people and blogs, films and animation, and certainly about education. By using YouTube when students are learning, it really helps them understand their English material and improve their learning performance (Almurashi, 2016).

Self Regulated Learning in the literature generally focuses on student's ability and motivation in implementing the learning strategies (Ertmer et al., 1996), as well as the motivations that triggers learners psychological aspects (Chang \& Wu, 2003). Monitoring and controlling strategy which is controlled by the students in Self-regulated learning (Garcia \& Pintrich, 1994) is very helpful for students in developing themselves about how to control their own learning, which is believed to be an important element to continue to be motivated in learning (Zimmerman, 1995). Students who are regulating their learning feel more motivated (Zhao, 2005) and students see SRL as an active learning process, rather than passively they choose to actively take control in controlling their learning process. Goal setting, monitoring, and controlling in self-regulated learning are important for the students to help them develop their senses in controlling their study (Zimmerman, 2000), in which the student's motivation to learn is considered an important major source. Success in the academic field is determined by a variety of factors; having control over the learning process itself is one of an important factor (Lewis \& Vialleton, 2011).

Several scholars have investigated the study of EFL students' self regulated learning using ICT. For instance, Lai and Gu (2011) have conducted a survey of students who in their learning process use technology outside the classroom, whether the use of technology affects the regulations in their 
language learning. The survey results show that using technology is very useful in helping students to learn, especially in terms of more learning materials, maintaining learning objectives, learning experience as well as maintaining students' motivation in language learning. Celik, Arkin, and Sabriler (2012) have conducted research on how to improve understanding self-regulated learners in using information and communication technology. Their results showed that there were no significant differences between male and female participants in using ICT for regulating their learning, as well as between learners' language levels. Practicing listening, vocabulary, and writing skills is what most students do in using ICT. Kizil and Savran (2019) have conducted research examining self-regulated language learning using ICT tools by EFL learners in outside of classroom settings. The results show that the use of ICT can be used to regulate several aspects of SRL. Students show positive behavior in affective regulation, regulation of resources as well as goal commitment. In addition there is only one study related to EFL students' self regulated learning using YouTube, Hung-chun \& Cheryl (2019) examine EFL learners in regulating their learning using YouTube while outside of the classroom, this research showed that the main intention of learning English using YouTube is to get more fun learning resources and gain cultural awareness.

However, there is only a dearth of studies concerning self-regulated learning using YouTube. Therefore, based on the previous study above this research propose to target this gap and set some insights of strength and weakness of self-regulated learning using YouTube deliberately in language learning in the midst of a special focal point on Indonesian EFL students' perception. The objective of this research is to deepen our understanding related to the students' perceptions as well as the strengths and weaknesses of self-regulated learning using YouTube. To sum up, the researcher identifies the research problem as follow:

1. What are Indonesian EFL students' perceptions of self-regulated learning using YouTube?

2. What are the strengths and weaknesses of self-regulated learning using YouTube?

\section{Method}

The method used in this research is qualitative with a descriptive case study design. The description in the case study is very focused and detailed by evaluating a sample in detail and depth, based on the articulation of descriptive theory (Yin, 2018). Meanwhile, the main objective in this study is to describe the data obtained from questionnaires and interviews which explain students' perceptions about self-regulated learning using YouTube and its strengths and weaknesses.

The participants of the study were purposively selected; they were four undergraduate students who are majoring in English education from university in Indonesia. The rationale of selecting the participants was due to those four participants already familiar in using YouTube and they have been regulating their learning English using YouTube outside the classroom. 
The research instrument used in this study is interview consist of several questions related to the research problem. The interview questions were formed based on the three components of perceptions defined by Walgito and Ahmadi (2013). The researcher did an in-depth interview with the subject of this research to gain adequate data to analyze.

In this study, an in-depth interview was carried out by means of recording and then after that the recording was transcribed. Interviews in this research were used to obtain main data to determine students' perception of selfregulated learning using YouTube as well as the strengths and weaknesses. Then after the data obtained from the interviews were collected, which data could be used as the main data and which should be eliminated because they could not be used. After that the data can be displayed in the form of a description. In the last stage is to verify the data and draw conclusions to answer the questions of this study.

\section{Findings and Discussion}

\subsection{Students' perception of Self-regulated learning through YouTube}

The objective of this study is to get the understanding of EFL students' perceptions of using the YouTube to regulate their learning, in-depth interviews were conducted. Meanwhile, interviews are constructed from three parts of perception, namely the cognitive, affective, and conative components (Walgito, 2010).

\subsubsection{Cognitive Component}

This part is connected to the thought, knowledge, as well as the beliefs of the participants in using YouTube for regulating their language learning. Through the data that was gathered from the interview, it showed that the four participants had a positive perception in using YouTube during their process of learning English in the cognitive realm. In terms of knowledge, participants already familiar in using YouTube for their self regulated learning. For example participant $\mathrm{C}$ representing the other participants said:

"It's been a long time since I used YouTube to learn English, so I know what must I do in using YouTube in helping me to continue my learning goals. I know how to use the features available on YouTube to support my study process". (Participant $C$ )

From the obtained data above, participant $\mathrm{C}$ acknowledged that on YouTube the participant can find diverse features that could be used in facilitating in the process of learning English, especially in self regulating their learning. Basically, the participants have been familiar in using YouTube. Students give positive thoughts regarding using YouTube for self regulated learning. For example, participants A and B said:

"Using YouTube is so much pleasure". (Participant A)

"YouTube is amazing and perfect to help me in learning English". (Participant B)

From the obtained data above, both participant $A$ and $B$ are having the same thought that the use of YouTube to regulate their learning was considered 
enjoyable in learning English. Then, participant B thought that YouTube was good and perfect in facilitating their learning outside of the classroom.

In addition, due to all of the participants have the same familiarity to use YouTube for self regulated learning; participants started having belief in YouTube. They are all indicated a positive cognition of their perceptions in selfregulated learning using of YouTube outside of their class. For instance, participant $\mathrm{B}, \mathrm{C}$ and $\mathrm{D}$ said:

"By regulating my own learning using YouTube, I could learn English pronunciation how to speak like native speakers, as well as practice my listening skills." (Participant B)

"YouTube really helps me in learning English. Just like when I want to learn about grammar, I can learn it. I can choose which video to learn that I like and I feel like I improve a lot of my vocabulary through watching videos on YouTube." (Participant $C$ )

"In my opinion, YouTube makes my learning English much easier and fun at the same time, because I can learn whenever I want, I can choose what to learn." (Participant D)

Based on the data above, it showed that YouTube give so many advantages for the students in regulating their learning, especially in learning English. Using YouTube outside of the classroom allow them to plan, monitor and evaluate their learning. All of participants $B, C$, and $D$ believed that when they used YouTube in regulating their learning, it helped and made it easier for them in various aspects such as fun material, they could learn anything anytime, improve vocabulary, and also understand grammar.

In the term cognitive, the students show a positive thought of selfregulated learning through YouTube. They agreed that YouTube is fun, enjoyable and suitable to support the learning process outside of the class. YouTube has so many advantages in supporting the participants' self regulated learning, especially in learning English. Using YouTube outside of the classroom allow them to plan, monitor and evaluate their learning. In this study, all participants believed that YouTube can help and support students in regulating their learning, especially in the following aspects of learning English such as speaking, listening, grammar, vocabulary, and pronunciation. The findings are supported by Watkins \& Wilkins (2011) and Alimemaj (2010) stated that YouTube videos have many advantages in the field of language learning. The same result was confirmed by Kelsen (2009) and Brandl (2012) who find out that YouTube videos seem increase the desire to break the routine and bring new things to the educational setting which will be fun and entertaining.

\subsubsection{Affective Component}

In the affective component refers to feelings or emotional dimensions that are not mediated by thoughts. Based on the data collected from interviews, the four participants effectively had positive

In this part of affective means oneself' emotions or feelings dimension which was not intercede by thoughts. Positive perceptions of the four 
participants using YouTube for self regulated learning especially in learning English are shown based on the data below. Participants A, B, C, and D said:

"I feel enjoy and more relaxed when I learn English using YouTube" (Participant A)

"When I feel that I get bored in learning English, using YouTube can help me to decrease the boredom and make the learning process more enjoyable". (Participant B)

"I feel like when I am learning English using YouTube I want it more and more, because it is just so interesting. I want to keep on doing it" (Participant C)

"Whenever I study using YouTube I just feel so excited" (Participant D)

From the interview, the participants admitted that they were feel the enjoyment to use YouTube in regulating their language learning as well as by using YouTube they can maintain their interest in learning English. Using YouTube, make the learning process more relaxing.

Additionally, on YouTube there are different features that students can use to support their learning process for example; search, play and pause, subtitle, playback speed, playlist, subscription, comment, like and dislike. Participants reveal the features they like and use the most in learning English. Participant $A$ mentioned the favorite feature in YouTube is Subtitle. Below are the displayed transcript interviews of participant $A$.

"It is easy to use YouTube in learning English, because I can just search

the materials that I want to learn". (Participant A)

Search engine of YouTube allow students to search anything that was uploaded on YouTube. So the participant can easily find the learning materials that desired just by searching it on YouTube. In addition, participant B and participant $D$ said that the feature they liked and used the most are subtitle features. Below are the displayed transcript interviews of participant B and D.

"Features on YouTube that I often use is Subtitles while I am practicing my listening skill". (Participant B)

"When I am learning speaking, sometimes native speaker speak too fast or I can't hear it clearly, so I activated the subtitle to help me in understanding the speaker". (Participant D)

Based on data above, participant $B$ and $D$ are prefers to use subtitle features, although not all videos have subtitles, almost all videos are available with subtitles in various languages, especially English.

Moreover participant $\mathrm{C}$ said that he liked and almost used all the available YouTube features.. Below are the displayed transcript interviews of participant C

"In my opinion, almost all available features on YouTube I like it and it is very useful to support my learning". (Participant C) 
From the interview data above, it shows that participant $C$ likes the features on YouTube which are very useful and can help students regulating their learning.

Furthermore, in this affective component the participants showed that they had positive perceptions when expressing how they felt about self-regulated learning using YouTube. Based on the results that have been found, the participants in this study stated that feel the enjoyment, can maintain their interest in learning English, and make learning process more relaxing. The results of this study are in line with previous research conducted by (Cavus \& Ibrahim, 2017)in their research it was found that using applications on students' smart phones to learn English had a positive impact on students, namely that it was more effective and fun than using books. Research which is also in line with Saunders (2013) found that learning to use material in the form of written text makes students quickly bored and ultimately does not pay attention.

Students have a positive perception of self-regulated learning using YouTube; this is also because the various YouTube features that exist are very helpful for students in the process of learning English. Search engine of YouTube allow students to search anything that was uploaded on YouTube. So the participant can easily find the learning materials that desired just by searching it on YouTube. The subtitle feature found in almost all YouTube videos is available in various languages, especially English. However, not all videos are available with this feature. However in self-regulated learning students can choose whichever video they like to learn English. All features in on YouTube were very useful in learning English. All the features contained in YouTube are very useful in supporting the self-regulated learning process, especially for learning English. All of that is supported by various useful features.

\subsubsection{Conative Component}

In this conative part, students' perceptions refer to how activities or actions are carried out by students. Based on the collected data through interviews, all of the participants showed positive perceptions in regulating their learning using YouTube in the cognitive domain. The participants describe some of their activities in regulating their learning to improve their English skills. For example participant $D$ representing participants $A$ and $B$ said:

"Before I start usually I set the goal, what I want to learn, and then selecting the materials on YouTube. Usually I will create a playlist on YouTube to make it easier for me in learning. Just like when I want to learn speaking skill, I search some videos that related to speaking such as pronunciation, accent, conversation, I will choose what I like and what I want to learn. so when the time I want to learn $i$ will just play the playlist, take note some important part, mimicking the way the native speaks and record it. Usually when I found difficulties I will asked my friends for help. I will listen to my own speaking practice that I have recorded then evaluate it, whether I did it right or not. For the next learning based on the evaluation I will decide what to learn, which video materials more suitable for the next learning". (Participant D) 
All students employed the process of self regulated learning; planning, monitoring and evaluating. Participants, in learning speaking enjoy recording their speech and checking whether their pronunciation is good or not. They are also seeking help from their friends.

Moreover in a term of conative, students' perception about their behavior or activity showed that all students employed the process of self regulated learning namely planning, monitoring and evaluating(Lewis \& Vialleton, 2011). Participants, in learning speaking enjoy recording their speech and checking whether their pronunciation is good or not. They are also seeking help from their friends.

\subsection{The strengths of Self-regulated learning using YouTube}

\subsubsection{YouTube provides a lot of learning materials}

The first strength of self regulated learning using YouTube is YouTube provide a lot of learning materials in learning English. For instance, participant $A$ and D said:

"I like learning English using YouTube because there are lots of video content for learning English". (Participant A)

"I can choose what I want, on YouTube there are lots of video materials for learning, just choose the appropriate one". (Participant D)

From those transcripts above, participant $A$ and $D$ showed an agreement that YouTube provide a lot of learning materials especially in learning English. Moreover they can download it freely and easily. YouTube provides a lot of learning materials, in line with, (Heriyanto, 2018) stated that YouTube has provided many opportunities for students to learn English with various types of videos which students can also improve their vocabulary.

\subsubsection{The ease in using YouTube}

The next strength, it is easy to YouTube for self-regulated learning. Participant B and C stated that:

"YouTube is very simple and easy to understand how to use it either using the YouTube application or via a browser". (Participant B)

"I like it because YouTube is very effective and easy to use". (Participant C)

Based on those transcripts above, participant B and D are agree that regulating their language learning using YouTube is very simple and easy. In using YouTube through application or browser, they have no difficulty in operating to regulate their learning. Using YouTube it is very simple and easy. YouTube could be access through application or even browser; students have no difficulty in operating to regulate their learning. In line with (Almurashi, 2016) the research pointed out that using YouTube videos is a relatively simple.

\subsubsection{Flexible in time and place}

The other strength that the YouTube offers when it comes to self regulated learning, it is very flexible in time. Actually it has huge benefit because students 
can learn whenever and wherever they want to. For example participants $A$ and B representing other participants' statement:

"I can learn English anywhere or anytime. Usually I study using my smart phones or computers to access YouTube". (Participant A)

"I can learn and practice English independently. It is up to me to study in the morning, afternoon, or even in the evening and wherever it is I feel comfortable to study". (Participant B)

From the data above, the participant $A$ and $B$ agreed with the flexibility provided by YouTube to self regulated learning. They describe how they learn English effectively and flexible. They can learn English anywhere and anytime, because they can easily access YouTube through their devices. Flexibility in learning must have at least one of the following components: learning style, learning material, time, place, or even assessment (Müller et al., 2019). Flexible learning makes students more independent and autonomous (Moran, 2013).

\subsection{The weaknesses of Self-regulated learning using YouTube}

\subsubsection{Financial constraints}

The first weakness of Self regulated learning using YouTube is Financial Constraints. To be able watching videos or even download it, cost expensive internet quota. For example, participant $B$ and $C$ said:

"When I learned English using YouTube it used up my internet quota, and buying internet quota was not cheap". (Participant B)

"When there is no Wi-Fi, to watch or download videos on YouTube in learning English, it consumes a lot of internet quota". (Participant C)

Based on the statement above, participant $B$ and $C$ are quite worry to use YouTube in regulating their learning because the cost was not cheap to buy internet quota. But it is going to help if there is Wi-Fi available for free so they can download the video materials first then learns it later.

\subsubsection{Problem of Internet Connectivity}

In addition, the other weakness of Self regulated learning using YouTube is Problem of Internet Connectivity. In accessing YouTube need the stability of Internet connection to make the process of learning going successfully. For example, participant $A$ and $C$ said:

"In my place sometimes the internet connection is not stable, so when I was learning using YouTube, suddenly the video could stop and I felt really annoyed". (Participant $A$ )

"Because the internet signal is bad, it takes a long time to download videos." (Participant $C$ )

As quoted in the transcript above, participant $A$ and $C$ was distracted because of the video suddenly stop and takes longer time to download the learning materials when the internet connection was not stable. In addition sometimes they need to find place for better connection or find place that has free Wi-Fi, in line with, (Casillano, 2019) stated students who have homes in 
areas with internet signal difficulties must look elsewhere to get a more stable internet connection.

\section{Conclusion}

This study shows the results that students have a positive perception of YouTube for self-regulated learning outside of the classroom. Regarding cognitive part, in this study all students showed that they had positive thoughts and believed that YouTube help them in regulating their language learning outside the classroom. According to participants' opinion, learning English using YouTube can solve problems such as boredom; lack of interest, motivation as well as YouTube has various types of interesting videos that can be used for learning materials. Based on affective aspect, the participants in this study expressed their positive feelings towards use of YouTube in self-regulated learning. All the students are excited in using YouTube because it brings them more fun and enjoyable learning. Moreover while in the conative aspect, the participants conveyed their positive activities during their process of learning using YouTube. All of them employed the process of self regulated learning namely planning, monitoring and evaluating. In addition the strengths of regulated-learning using YouTube are YouTube provides plentiful of learning materials, the ease to use YouTube, flexible of time and place using YouTube. Meanwhile the weaknesses are financial constraints and problem of Internet connectivity.

\section{References}

Almurashi, W. A. (2016). The Effective Use of YouTube Videos for Teaching English Language in Classrooms as Supplementary Material at Taibah University in Alula. International Journal of English Language and Linguistics Research.

Brandl, K. (2012). Effects of required and optional exchange tasks in online language learning environments. ReCALL. https://doi.org/10.1017/S0958344011000309

Casillano, N. F. B. (2019). Challenges of Implementing an E-Learning Platform in an Internet Struggling Province in the Philippines. Indian Journal of Science and Technology, 12(10), 1-4. https://doi.org/10.17485/ijst/2019/v12i10/137594

Cavus, N., \& Ibrahim, D. (2017). Learning English using children's stories in mobile devices. British Journal of Educational Technology. https://doi.org/10.1111/bjet.12427

Chau, C. (2010). YouTube as a participatory culture. New Directions for Youth Development. https://doi.org/10.1002/yd.376

Ertmer, P. A., Newby, T. J., \& MacDougall, M. (1996). Students' responses and approaches to case-based instruction: The role of reflective selfregulation. American Educational Research Journal. https://doi.org/10.3102/00028312033003719

Garcia, T., \& Pintrich, P. R. (1994). Regulating motivation and cognition in the classroom: The role of self-schemas and self-regulatory strategies. Self- 
Regulation of Learning and Performance: Issues and Educational Applications.

Hadijah, S. (2016). Teaching by using video: Ways to make it more meaningful in EFL classrooms. Proceedings of the Fourth International Seminar on English Language and Teaching ISELT-4.

Heriyanto, D. (2018). The Effectiveness of Using Youtube for Vocabulary Mastery. ETERNAL (English Teaching Journal). https://doi.org/10.26877/eternal.v6i1.2290

Kelsen, B. (2009). Teaching EFL to the iGeneration: A survey of using YouTube as supplementary material with college EFL students in Taiwan. Call-EJ Online.

Lewis, T., \& Vialleton, E. (2011). The notions of control and consciousness in learner autonomy and self-regulated learning: A comparison and critique. Innovation in Language Learning and Teaching. https://doi.org/10.1080/17501229.2011.577535

McLoughlin, C., \& Lee, M. J. W. (2010). Personalised and self regulated learning in the Web 2.0 era: International exemplars of innovative pedagogy using social software. Australasian Journal of Educational Technology. https://doi.org/10.14742/ajet.1100

Merchant, G. (2009). Web 2.0, new literacies, and the idea of learning through participation. English Teaching.

Mokhtari, K., Delello, J., \& Reichard, C. (2015). Connected yet distracted: Multitasking among college students. Journal of College Reading and Learning. https://doi.org/10.1080/10790195.2015.1021880

Moran, L. (2013). Introducing flexible learning. 2009, 1-21. www.deakin.edu.au/itl/.../flexiblelearning-m2.doc

Muhammad, A.-I., Alqahtani, E. T., Na'eem, O., \& Abdelrahman, B. (2014). Kingdom of Saudi Arabia Ministry of Higher Education Effectiveness of Using YouTube on Enhancing EFL Students' Listening Comprehension Skills Riyadh-Saudi Arabia. 1-62.

https://www.awej.org/images/Theseanddissertation/EbtissamAlqahtani/ebti ssamalqahtanifullthesis.pdf

Müller, C., Stahl, M., Alder, M., \& Müller, M. (2019). Learning Effectiveness and Students' Perceptions in A Flexible Learning Course. European Journal of Open, Distance and E-Learning, 21(2), 44-52. https://doi.org/10.2478/eurodl-2018-0006

Rahman, F., \& Amir, P. (2019). Trends in Reading Literary Fiction in Print and Cyber Media by Undergraduate Students of Hasanuddin University. International Journal of Education and Practice, 7(2), 66-77.

Thorne, S. L., Black, R. W., \& Sykes, J. M. (2009). Second language use, socialization, and learning in internet interest communities and online gaming. Modern Language Journal. https://doi.org/10.1111/j.15404781.2009.00974.x 
Walgito, B. (2010). Pengantar Psikologi Sosial. Yogyakarta: Andi Ofset.

Watkins, J., \& Wilkins, M. (2011). Using YouTube in the EFL Classroom. Language Education in Asia. https://doi.org/10.5746/leia/11/v2/i1/a09/watkins_wilkins

Zhao, Y. (2005). Technology and Second Language Learning: Promises and Problems. Flora, January, 1-31.

Zimmerman, B. J. (1995). Self-Regulation Involves More Than Metacognition: A Social Cognitive Perspective. Educational Psychologist. https://doi.org/10.1207/s15326985ep3004_8

Zimmerman, B. J. (2000). Attaining self-regulation: A social cognitive perspective. Handbook of Self-Regulation. 